10. Pasmor, N. (2015). Web site and social networks as a means of online representation of the university library. Proceedings from XVIII The Sixth International Scientific and Practical Conference "Korolenkov Readings 2015. Libraries, Archives, Museums: Innovative Development Models" (pp. 85-94). Kharkiv [in Ukrainian].

11. Pryhornitskaya, O. (2018). Library blogs as a tool for promoting a library in a virtual space http:// conference.nbuv.gov.ua/report/ view/id/340 [in Ukrainian].

12. Ryzha, M. (2010). Library blogs and pages in social networks URL: http://www.rdobd.com. ua/?catid $=56: 2010-08 /$ [in Ukrainian].

13. Savchuk, T. (2011). Website of the University Library: Basic Concepts of Construction and Development Trends URL: http://ir.lib.vntu.edu.ua/handle/123456789/32/ [in Ukrainian].

УДК $025.4(430)$

Lorenz, Bernd,

$\mathrm{PhD}$, Associate Professor,

Munich University of Applied Science, Germany bernd.lorenz@bsb-muenchen.de http//orcid/0000-0003-3292-9896

\title{
THE CLASSIFICATION OF REGENSBURG: HISTORY AND DEVELOPMENT
}

The purpose of this article is giving on overview of the development of the Classification of Regensburg, which was created in 1964 by specialists at the Regensburg University Library. The methodology is based on historical and classification principles and methods. Particular attention is paid to comparative method. Scientific novelty. The main characteristics of the classification scheme Regensburg, which combines: introduction, peculiarities of organization, basic concepts, subject classes, revision policy, is presented. Conclusions. The Classification of Regensburg has become widespread for the indexation of funds in academic libraries of Germany, as well as of other countries in particular Austria and Switzerland. Updating of subject schemes of the Classification of Regensburg started in the 90ies of the 20th century. Since 2009 an online version of the Regensburg Classification system has being developed and improved. The main principles and changes made in 2017 have been specified.

Key words: library classification systems, the Classification of Regensburg, classification schemes, organization of knowledge, online classification for libraries documents.

Лоренц Бернд, $\mathrm{PhD}$, доцент, Мюнхенський університет прикладних наук, Німеччина

\section{КЛАСИФІКАЦИЙНА СИСТЕМА РЕГЕНСБУРГ: ІСТОРІЯ ТА СУЧАСНИЙ РОЗВИТОК}

Метою роботи є висвітлення розвитку німецької бібліотечної системи класифікації, яку було впроваджено у 1964 роиі фахівиями університетської бібліотеки в Регенсбурзі. Методологія базується на використанні історичних та класифікаційних принципів і методів. Особливу увагу приділено застосуванню компаративного методу. Наукова новизна полягає в тому, що презентується основний ряд класифікаційної схеми Регенсбург, який поєднує: вступ, особливості організації, основні концепти, предметні класи, політику ревізії. Висновки. Зазначається, що 
класифікачія Регенсбург набула значного поширення для індексачії фондів в академічних бібліотеках Німеччини, а також у бібліотеках інших країн, зокрема Австрії, Швейчарії. 3 1990-х років ХХ ст. розпочато оновлення ї̈ предметних схем. 32009 р. у співпрачі з партнерами розробляється та удосконалюється онлайн версія класифікації. Акиентовано увагу на ї̈ основних принципах та характеристииі змін, здійснених у 2017 роиі.

Ключові слова: бібліотечні класифікаційні системи, класифікащія Регенсбург, класифікаційні схеми, організачія знань, онлайн класифікачія бібліотечних документів.

Лоренц Берно,

$\mathrm{PhD}$, доцент,

Мюнхенский университет прикладных наук, Германия

\section{КЛАССИФИКАЦИОННАЯ СИСТЕМА РЕГЕНСБУРГ: ИСТОРИЯ И СОВРЕМЕННОЕ РАЗВИТИЕ}

Целью статьи является освещчение развития немецкой библиотечной классификационной системы, которая была внедрена в 1964 году специалистами университетской библиотеки в Регенсбурге. Методология основывается на использовании исторических и классификационных приниипов и методов. Особенное внимание уделяется использованию компаративного метода. Научная новизна состоит в презентачии основного ряда классификащионной схемы Регенсбург, в которой представлены: введение, особенности организации, основные концепты, предметные классы, политика ревизии. Выводы. Отмечается, что классификаиия Регенсбург получила значительное развитие для индексачии фондов в академических библиотеках Германии, а также в библиотекахдругих стран, в том числе Австрии, Швейцарии. С 1990-х г2. ХХ века началось обновление ее предметных схем. С 2009 р. в содруженстве с партнерами разрабатывается и усовершенствуется онлайн версия классификации. Акцентировано внимание на основных принципах классификаџии и характеристике изменений, которые были осуществлены в 2017 г.

Ключевые слова: библиотечные классификационные системы, классификаиия Регенсбург, классификационные схемы, организачия знаний, онлайн классификация библиотечных документов.

\section{Introduction}

Many university libraries in Germany are managed by a so-called two-track system with one central library and a range of greater or smaller decentralized institute or faculty libraries. Here the books are often organized according to an inhouse classification scheme many of them often years old.

Just the contrast: The University Library of Regensburg was founded in the year 1964, the library was built to serve as a collection of books on open-access shelves. Consequently, it is essential in an openshelf library that the books (journals, newspapers and so on) are categorized. Thus the central task on which the others depend is the organization of the collection - the arrangement of the documents in some helpful order: here in a new classification scheme.

For some time it has been clear that the Regensburg Classification Scheme has deserved a presentation along the lines of those existing for other general classification schemes. There are several reasons for this. One is the need to provide information to a wider international audience. Another is to bring together the experience of specialists in classification theory and those working with classification. We know that practicing librarians are busy, students are grappling with a crowded curriculum - and the relevant literature (print and/ or electronic) is often scattered.

Consequently, the purpose of the text is to continue to provide an exposition of the Regensburg (Network) Classification and a tool for studying and for staff training in the use of the scheme. Keeping in mind that - during the 60's - it was the exception in Germany for users of academic libraries to be given direct access to the shelves. Normally the users have to refer to the catalogs (often called the heart of the library!) to find what $s /$ he wants. Since a century the consensus of the main classification schemes seems to be that systematic arrangement by subject is the 
most useful of the choice of author, title or alphabetical subject.

But the good functional grouping of subject matters depends on the prior structural organization of knowledge in the form of a sound and useful classification system, of course. Indeed, the fundamental importance of classification and classificatory structure in all kinds of information systems and knowledge organization systems seem now to be clearly understood. We may conclude that library classification is knowledge classification with necessary adjustments, such as the provision of generalia class, common isolates, form classes, notation, book number and so on.

\section{A brief history}

2.1 A new classification for the new established open-access library

In this way, the classification system of the library has been developed keeping browsing in mind. The philosophy of open access is based on a commitment to library service. Only a few types of document cannot be put into classified order. This idea of the good neighborhood of books (and texts) is based on the assumption that researchers - in the humanities, above all - tend to seek information and create use of literature by browsing among the library stacks. Theoretically, it helps them to find the unexpected, the item that would not have been found otherwise.

The result has been that the open-access library with the simplicity of the arrangement of the collection, in particular, owes much of its efficiency to the flexibility and usefulness of its classification system. After studying the possibilities of adopting one of the major published classification schemes mentioned above in the context of a special so-called German unitary classification scheme ("Einheitsklassifikation") being in discussion during the 70's, than was finished without success - the Regensburg University Library established a new "home-made" classification for its own open-access library created by working-groups of experts in humanities or sciences and library.

\subsection{From the beginning}

The Regensburg classification scheme was originally designed and developed as a utilitarian system to classify the - mainly new - books of the Regensburg collection and for future expansion of the collection - with regard to the requirements of library staff, public, academic people, and students. In this way, users were involved in negotiating classificatory structures. - And above all: This new system was not intended for use by any other library.

Max Pauer, a chief librarian of Regensburg 1964-1989, emphasized the practical considerations as an important basis for the development of the Regensburg classification scheme. At the same time, the library staff started to work more intensively with theoretical considerations in mind. For this reason, understanding the relationship between classification and browsing is essential for librarians and information scientists. Thus a successful classification system should minimize the amount of user-time spent browsing.

Therefore more effort has been expended in developing aids for using the classification scheme. Like most university and other academic libraries - which do not have open stacks and have tended to develop in-house schemes - in Germany, Regensburg developed a separate classification scheme for the years 1964-1969, similar in essence to LCC which was used for shelfmarks and in the stack. For the class-marks are not too complicated for a messenger to find the right book when sent to the stacks to fetch a work or for a reader to approach the shelves.

\subsection{Classification of a growing group of} academic libraries

But unlike most university and other academic libraries in Germany, Regensburg has developed its classification in line with the classification of a large group of German academic libraries. This classification, as it has been stressed, was originally only intended for the University of Regensburg but it has also been employed with success elsewhere. Other academic libraries, therefore, use the same classification scheme and they employ it with only a few minor modifications. In the meantime, the principle of open access to library collections is a characteristic of a lot of German academic libraries.

The history of this development shown in the following six main steps:

a) Since 1970 an extensive cooperation is going on with the newly founded Augsburg University Library, followed by the other new university libraries in Bavaria, and also with the old and famous university libraries of Erlangen and Würzburg (1982). 
b) Since 1983 a group of other libraries mainly polytechnics - in Bavaria with predominantly technical interests have been working together with Regensburg and its partners and have begun to use the classification scheme (partly reclassifying from the formerly used Universal Decimal Classification).

Once being aware of the existence of an improved system, librarians and academic people are faced with a decision to reclassify or not. This decision evaluates the ultimate economy in service against initial costs. A delay in making the change will cost more in the long run. In some situations, a plan of gradual changeover might be appropriate, such as involving more recent acquisitions. The main point has been to try to choose a scheme which will meet the needs of the users while remaining within the economic framework of the organization using it.

c) In the neighboring countries of Germany exist also users of the Regensburg classification scheme, for example the University Library of St. Gallen (Switzerland) - since 1986 - and the Town and University Library of Bern - since 1999; also the Library of the Fachhochschule Liechtenstein at Vaduz (Liechtenstein) and in 2000 the University Library of Innsbruck (Austria). In the meantime, the largest group of academic libraries in Austria uses the Regensburg classification - with an Austrian user group and a special arrangement for the juridical libraries according to Austrian law.

Analogically works for the user group in Switzerland.

d) The most significant developments in Germany have taken place since 1990 The unification of Germany brought together the "Regensburg classification group" (i.e. the group of academic libraries using the Regensburg classification scheme) with a large number of important university libraries and other scientific libraries of the former GDR.

Thus a large number of famous libraries like the "Humboldt-Universität Berlin" (the traditional University of the capital), Chemnitz, Dresden, Greifswald, Leipzig and Rostock (in alphabetical order) and the "Herzogin Anna Amalia Bibliothek" Weimar in 2001 have become users of the classification scheme and at the same time cooperating partners in the on-going work of improving the classification scheme. As a rule, this process started when the university library began using the classification for current materials: classificatio est semper reformanda.

At the same time the newly opened university libraries like the ones in Erfurt, Frankfurt/ Oder and Potsdam have become users of the classification scheme.

In 1991, the university library of Munich ("Ludwig-Maximilian-Universität") chose reluctantly to utilize the centralized classification of Regensburg and the "Regensburg classification group". In the meantime, the greatest and most important part of the collection was reclassified by the Regensburg Classification scheme.

In 1993 the research of Hans-Joachim Zerbst and Olaf Kaptein in "Bibliotheksdienst" 27, 1993 pp. 1526/1539 showed that the Regensburg Classification Scheme has a special significance for German academic libraries.

e) In 1998 the newly founded University of Bozen and Brixen (Southern Tyrol, Italy) has started to use the Regensburg Classification and to translate important parts of it into Italian (the second official language in Southern Tyrol) at the same time:

Generalita (A)

Psicologia (CL-CZ)

Pedagogia (D)

Sociologia (MN-MS)

Giurisprudenza (P)

Scienze economiche $(\mathrm{Q})$

Agricoltura e foreste(ZA-ZE)

And - a little later - into English (the third

language of the university at Bozen).

Jurisprudence (P)

Business and Economics (Q)

with minor expansions and cultural adaptations.

A few years earlier the university library of Frankfurt/Oder had successfully begun to write a Polish adaptation. In the following decennium, a number of scientific libraries of the province of Southern Tyrol have chosen the classification for the institution.

How many and what kinds of libraries use the Regensburg Classification? The system, therefore, serves as an exemplary classification which proven success in many academic - see above and other libraries (e.g. school libraries, museum libraries, libraries of monasteries). By using and 
criticizing the Regensburg Classification it has to be considered that the classifiers are dealing with millions of books in more than 70 academic and more than 70 other libraries. Versions of the classification used at a few libraries only vary somewhat from the official text. There are also a few expansions of the text in use by single libraries.

f) The renewed Regensburg Classification

In 2009 the University Library Regensburg reorganized the classificatory work with the partners. A narrow circle of users/partners makes conduct with Regensburg and pays a little fee for organizing a better technical and electronic support for the classification work done by the Regensburg Library. Since more than a decade the classification is given electronic with more and more possibilities to use. In the ' 60 s the classification is machine-written, consequently in following numbers of editions for each volume since nearly ten years the classification in all of its parts is actually and correctly published each three-months tact.

3 Notation system - The new classification - formally similar to LCC

The Library of Congress Classification and the Dewey Decimal Classification - as the most famous and used classification systems worldwide - were also considered to be too strongly based in (Anglo-)American thought, of the 19th century particularly - were used to a new German university library founded in the $2 \mathrm{~d}$ part of the 20th century like Regensburg or a German academic library in General.

However, serious consideration was given to the method of mixed notation of double letters and following numbers used for LCC - according to an enumerative classification. From a theoretical viewpoint, Regensburg's notation is certainly adequate.

Like LCC, a Regensburg classmark consists in general of three key elements: location number, classification number and author marks (formulated by C. A. Cutter, revised by Kate E. Sanborn). Consequently, a correspondence does not always exist between the length of the classmark and the hierarchical structure of the classification system.

The author symbols are composed of an initial letter followed by Arabic numerals. To these may be added symbols designating a particular title and/or a particular edition.

Length of notation - Let's take for example:
Eric John Dobson: English pronunciation 1500-1700

\begin{tabular}{|c|c|c|}
\hline $65 /$ & 190 & D635 \\
\hline Location number Modern & Phonetics & Author Edition Volume \\
\hline English & & $(\mathrm{CSN})$ \\
\hline
\end{tabular}

(Each departmental library has its own separate number as a part of the shelving arrangement.)

In practice, there are also some auxiliaries like special author tables used in classifying the works of prolific authors such as St. Augustine and Adorno, especially where it is desirable to group with the works all the books about the works. In general, we will also conform to the law of economy. It seems that we have to accept a loss in specificity and thus a poorer relevance performance in order to have a practical shelf arrangement notations. However, the user does not find it too difficult to scan a shelf full of books.

\section{The Classification Scheme \\ 4.1 Introduction}

A total of 34 (originally physical volumes mentioned above) parts comprise the Regensburg classification schedules.

The individual schedules are primarily kept up-to-date by:

- Newsletters (semi-annual as a rule), published by the secretary for the coordination of the classification at Regensburg with three units:

- State-of-the-Art, including program and results of working groups

- Additions, modifications, and corrections of single notations and of groups of notations

- On-going contact between specialists and the secretary for coordination

Each schedule has a similar, even identical format:

A prefatory note a brief history of the schedule is part of the last machine-written edition or you can find it in the "Handbuch für die Regensburger Verbundklassifikation" third edition (2017)(Manual for the Regensburg Network Classification).

In some schedules additionally, some general instructions accompany the usual elements making up each schedule.

The classification uses an alphabetical notation $\mathrm{A}-\mathrm{Z}$ for the main classes.

Like class P of LCC, the philological sched- 
ules E-K of the Regensburg classification contain over one.

A third of the content of the entire classification scheme.

Nevertheless the schedule "Technology" has assumed an ever-growing significance since the years 90'.

\section{Arrangement:}

As a modern book classification, the Regensburg Classification arranges books primarily by subject, but many other methods are used in the final arrangement on the shelves. In particular, the author and title arrangements are employed within the specific classes. There is no reason why alphabetical order should not be used, to a certain extent, within the classification scheme whenever it is the most sensible method of subarrangement or whenever it can bring about a more useful grouping than a classified sequence can; yet the alphabetical arrangement can only justifiably replace a classified one if we are sure that no loss of efficiency results.

Many of the schedules also provide common geographical divisions, although they may not always use this term to denote them.

There are many "see" and "see also" references too in the schedules since no book classification gathers together at one point all that a reader may require on a topic. The collocation of related topics and the possibility to browse may be at least as important as specificity and the provision of unique locations. Ease of use by the indexes is a consideration for the general system of classification also, and the encoding of complex relationships between components is intellectually demanding and time-consuming to implement.

The classification does not officially provide alternative or optional numbers. Therefore alternatives are often not indicated as such but given in the form of these parenthesized numbers with "see" and "see also" references. Such numbers may be used as an alternative - but correctly constructed - class numbers by other libraries of the network. Among suitable cases for alternative placings are Education, Political Science, and Law. Indeed Biochemistry could go under Biology or under Organic Chemistry.

Concepts in Classification:

It is obvious that great effort has been made by Regensburg classifiers to economize on sched- ule space by the use of tables applicable to a large number of cases, and when it has not been done it is because it is not feasible in view of the special nature of the matter to be classified.

Indeed book classification is a classification of knowledge with adjustments conditioned by the physical form of books. The library environment is one of the institutionalized forms of knowledge organization since it is concentrated a certain part of the documented world of public knowledge and the world of individual knowledge of librarians and users also. Nevertheless, the schedules of a book classification must, of necessity, be of a more permanent nature than those of classification of knowledge. Thus revisions are absolutely necessary for the classification to give the scheme an updated style and a contemporary outlook. In general, the classification schedule should omit no step in the hierarchy.

The problem of keeping pace with knowledge is not restricted to the classified arrangement, of course. Terminology changes, new terms have to be introduced, new relationships arise, and all these changes will affect any system, systematic or alphabetical. Indeed terminology has always been a fundamental factor in the theory and design of information structures, but its role in the research of classification and knowledge organization, in general, is growing.

\section{Revision policy:}

Therefore subject specialists at Regensburg and the partner libraries developed and continue to develop each of the individual schedules by consulting academics - according to changing types of literature used in single sciences.

Five basics are fundamental for the interchange of classification and science:

- Fiction/Theory: What are the connections?

- Facts: What are the trends and developments?

- Functions: What are the aims of the two branches?

- Feeling/Emotional factor: Is very important for working together with success!

- Future: New Themes and sciences demand some corrections or new possibilities in classification.

The full editions make steady if unspectacular, progress and are mainly devoted to the Sciences (and Humanities of course). Revision is 
on-going; one has to acknowledge the very practical attitude of the team of compilers - chosen groups of specialists in various themes and in librarianship.

The terminology used in the text should be as up to date as possible consistent with the usage of the users. In the meantime basis of terminology consists the common normed data ("Gemeinsame Normdatei") used on the majority of libraries in German-speaking countries.

It must be stressed that this classification is essentially a team product and that, in many ways, it is the best thought of as a coordinated series of special classifications. Thus the Regensburg Classification is under constant and consequent development and revision in the Editorial Office at the Regenburg University Library. This editorial office helps customers in arranging access to the classification - together with the IT-Department of the library and his growing importance for many years.

A new development since the year 2017: For a single scheme or a group of schemes works a group of experts and for the development and progress of the whole classification is established a council ("Beirat"). Interested libraries can get texts and brochures to the classification and/or participate in courses for the introduction.

4.2 University of Regensburg Library Classification Scheme: The Individual Schedules

A

General. Bibliography. Encyclopedias (General). General reference works. Uni versities. Libraries and library sciences. In formation science.

Environment

B Theology. Religion

CA-CI Philosophy

CL-CZ Psychology

D Education

E General and comparative linguistics and philology. Indo-European languages. Extra-European

Languages and literatures

F Classical languages and literatures

(Ancient, Medieval, and Modern)

G Germanic languages and literatures

$\mathrm{H} \quad$ English (British English, American

English). English literature worldwide
I

$\mathrm{K}$

LA-LC

LD-LG

LH-LO

LP-LZ

MA-MM

MN-MS

$\mathrm{MX}-\mathrm{MZ}$

$\mathrm{N}$

$P$

Q

$\mathrm{R}$

SA-SP

SQ-SU

TA-TD

TE-TZ

$\mathrm{U}$

$\mathrm{V}$

$\mathrm{W}$

$X A-Y Z$

ZA-ZE

ZG-ZS

ZX-ZY
Romance languages and literatures

Slavonic languages and literatures

Ethnology. Ethnography

Classical Archaeology

Fine Arts

Music and Musicology

Political Science

Sociology

Military Science

History (including Auxiliary sciences)

Jurisprudence

Business and Economics

Geography

Mathematics

Information technology

Natural Science (General)

Geology and Paleontology

Physics

Chemistry and Pharmaceutics

Biology

Medicine

Agriculture. Forestry. Horticulture.

Fishing. Home Economics

Technology

Sports

(Formerly: O Students' library; no longer part of the official classification scheme.)

4.3 Support for classification work:

Publications:

Stringent and comprehensive instructions on how to use the classification are very important, above all when working within a definite group of participants. Therefore exists a number of aids for classification:

- Rules for the assignment of bookmarks; at the same time practical guide.

The most important things that the Regensburg University Library learned were that classifiers in a great need of assistance, and that workshops (above all in-house-workshops for one library) and a Manual (published 2003, second edition 2008, third edition 2017) were absolutely necessary. The rules explain how to apply classification schedules and to build class numbers, and is a helpful source of advice for using the classification in general with a number of examples and explanations given in the text.

- Newsletter vol. 1-, 1985- 
A recurring problem is how to inform the libraries about the classification policies. The Newsletter

- a nearly traditional support for classification work - is the primary channel of communication and information. Here the announcements related to classification and shelf-listing are immediately relevant.

- RVK-Bibliography: a survey of works and articles about the Regensburg classification scheme (see: https://rvk.uni-regensburg.de/ueberdie-rvk/45-literatur-rvk-regensburger-verbundklassifikation /52-bibliographien-und-schrifttum - Indexing:

There are some indexes for additions and auxiliaries to fifteen of the 34 individual schedules and lists of authors/names for seven. Provided that the documents are classified as fully as the classification scheme allows, these alphabetical subject indexes of the individual schedules and the general index of the classification (shown as a level of the online classification) - both arranged according to the (German) subject-heading authority file ("Gemeinsame Normdatei", mentioned above) - should prevent the same subject under being entered synonymous terms. Thus, some related subjects separated in the classification will be brought together through verbal similarities.

Moreover, there are many "see" and "see also" references in the indexes.

5 Classification in progress

a) Plans and projects

Our plans in the field of classification for the next years include:

- Updating according to developments in the sciences and humanities

- Revision of auxiliary tables and indexes

- Further development of the On-line Classification: based on a project (1995-1997) at the University of Regensburg Library supported by Deutsche Forschungsgemeinschaft (German Research Organization).

(http://www.bibliothek.uni-regensburg. de/Systematik/systemat.html)

As far as possible, the library and the partners want to maintain and develop the Regensburg Classification as a tool for the organization of knowledge. Therefore it is attempting to meet the needs of users in a variety of different circumstances and areas.
Within this emerging network, the classification scheme constitutes a discursive arena facilitated by the libraries and functions as a boundary object for the various interests that exist among users and librarians.

To this end, it is argued that the library should be an active part in the production of knowledge and that this role can be affected by the development of classificatory structures.

Vocabulary management:

Therefore the reliability of indexing and classifying and, hence, the quality of the searches can considerably be improved through the use of advanced techniques of vocabulary management, for example, through the interactive display of the hierarchies in classification and vocabulary on the screen.

Research environment:

Certainly, the foundations of a library classification scheme can be safely laid by thinking of it as a language. At the same time library classification, which is subject to the mechanical and financial restrictions, has insurmountable limitations imposed on it by the multiplicity of helpful ordering among specific subjects. It is the knowledge of this very limitation which makes library classification look for help from outside. Some help is possible from another tool common among librarians:

Subject headings to self-contained independent, bibliographical units, e.g. monographic works.

There should be necessary to lay emphasis on the key role of subject cataloguing/content finding in libraries. The potential usefulness of library materials cannot be exploited without it. Thus the process of subject analysis is generally realized through the assignment of classification numbers and subject headings.

\section{In future:}

There is a need for online classification data to:

- use classification numbers for validation, global changes, and links to subject headings

- enhance subject access, automate shelflist functions

- incorporate online classification data into a workstation numbers

- provide timely updates to classification

$$
\text { - assist in the task of reclassification }
$$


- work at a number of concordances.

It is important to receive information and communication to help in this planning from colleagues working in the field of classification.

Summary

The University of Regensburg was founded in 1964 as a collection of printed material on open-access shelves. Therefore the library established a new "home-made" classification scheme.

Like LCC, a bookmark consists in general of three principal elements: location number, classification number, and author marks (formulated by Cutter and Sanborn).
But unlike most academic libraries in Germany, Regensburg has developed its classification in line with the classification of a large group of academic libraries in Germanspeaking countries. Thus the Classification is most wide-spread in Central Europe.

The 34 individual schedules are primarily kept up-to-date online and organized by the secretary for the online classification (working center) at Regensburg; the basis is the continuous contact between the specialists of the partners and the secretary.

\section{References}

1. Geisselmann, Friedrich "Online-Version einer Aufstellungssystematik", in: Aufbau und Erschließung Begrifflicher Datenbanken. Beiträge zur bibliographischen Klassifikation. H. Havekost / H.-J. Wätjen (Hrsg.) (Oldenburg, 1995), p.131-151.

2. Häusler, Ines - Werr, Naoka Die Regensburger Verbundklassifikation (RVK), in: Klassifikationen in Bibliotheken. Theorie - Anwendung - Nutzen. H. Alex, G. Bee und U. Unger (Hrsg.)(Berlin/Boston, 2018), p. 127-163.

3. Lorenz, Bernd 50 Jahre RVK: Bedarf - Beobachtungen - Bewertung http://rvk.uni-regensburg.de/ images/stories/Conf2014/lorenz

4. Lorenz, Bernd Handbuch zur Regensburger Verbundklassifikation. Materialien zur Einführung. Unter Mitarbeit von R. Achenbach, K. Boll-Becht, I. Häusler, V. Plößnig, Gerald Peichl und N. Werr, Hrsg. B. Lorenz (Wiesbaden, 3 überarbeitete Aufl. 2017).

5. Lorenz, Bernd The Regensburg Classification: A Short Survey, in: Cataloging and Classification Quarterly 25, 1997, p. 39-49.

6. Lorenz, Bernd The Regensburg Classification Scheme: Users and Partners, in: Knowledge Organization 22, 1995, p. 159-161.

7. Pauer, Max Deckung von Aufstellung und Systematischem Katalog. Wunsch und Wirklichkeit in Bibliothekssystemen der neuen bayerischen Universitäten, in: Bestandserschließung und Bibliotheksstruktur. Rolf Kluth zum 10.02.1979. Hrsg. R. Alsheimer (Wiesbaden, 1979), p. 158-169.

8. Werr, Naoka - Ball, Rafael Die „neue“ Regensburger Verbundklassifikation (RVK) oder die Zukunft eines Erfolgsmodells, in: Bibliotheksdienst 43, 2009, p. 845-853. 